International Journal of Electrical Engineering and Technology (IJEET)

Volume 11, Issue 4, June 2020, pp. 114-121, Article ID: IJEET_11_04_013

Available online at https://iaeme.com/Home/issue/IJEET? Volume $=11 \&$ Issue $=4$

ISSN Print: 0976-6545 and ISSN Online: 0976-6553

DOI: https://doi.org/10.34218/IJEET.11.4.2020.013

\title{
STABILITY ANALYSIS OF PROPORTIONAL INTEGRAL AND FUZZY CONTROLLER FOR MODIFIED RESONANT CONVERTER UNDER VARIOUS DISTURBANCES
}

\author{
G.G. Muthukumar \\ Assistant Professor, Department of Electrical and Electronics Engineering, \\ Mailam Engineering College, India \\ N. Madhanakkumar \\ Associate Professor, Department of Electrical and Electronics Engineering, \\ Mailam Engineering College, India

\section{G. Irusapparajan} \\ Professor, Department of Electrical and Electronics Engineering, \\ Mailam Engineering College, India

\section{Sriramkumar} \\ PG Scholar in Power Electronics and Drives, \\ Mailam Engineering College, India
}

\begin{abstract}
In general, resonant converter can perform better in terms of reducing switching losses, high efficiency, less weight and high power density. In addition, operating regions of series Resonant Converter (SRC) is large when compared to parallel resonant converter (PRC) and series-parallel resonant converter. The main advantage of using a dual bridge resonant converter is to extend the output voltage range, high power density, high efficiency and widen soft switching ranges. The proposed resonant converter is dual bridge series resonant converter with dual tank circuit [14] incorporating Proportional Integral (PI) and Fuzzy controller. The dual tank circuit can extend the ZVS region, so that switching loss can be reduced. In this paper, the stability analysis of the proposed system was obtained under the application of line and load disturbances.
\end{abstract}

Key words: Fuzzy Controller, Proportional Integral (PI), Resonant Converter

Cite this Article: G.G. Muthukumar, N. Madhanakkumar, G. Irusapparajan and V. Sriramkumar, Stability Analysis of Proportional Integral and Fuzzy Controller for Modified Resonant Converter Under Various Disturbances, International Journal of Electrical Engineering and Technology, 11(4), 2020, pp. 114-121. 
https://iaeme.com/Home/issue/IJEET?Volume $=11 \&$ Issue $=4$

\section{INTRODUCTION}

Resonant converters mainly consist of three parts, (i) Inverter side (ii) Resonant tank and (iii) Rectifier side. The soft switching techniques are applied in resonant converters. Especially, in inverter side ZVS is achieved and in rectifier side ZCS is achieved [2]. Dual Tank and Dual Bridge Series Resonant Converter (DTDBSRC) incorporating Proportional Integral and Fuzzy controller was proposed [5-7]. Also, different time domain specification parameters were obtained to study the stability of the system. Basic introduction about proposed converter has been discussed in this section I. proposed topology and design has been discussed in II. Simulation results of the proposed system have been discussed in section III. Various performance parameters and stability analysis of the proposed topology incorporating Proportional Integral and Fuzzy controller have been discussed in IV. In section V, conclusion has been discussed.

\section{DTDBSRC - PROPORTIONAL INTEGRAL AND FUZZY CONTROLLER}

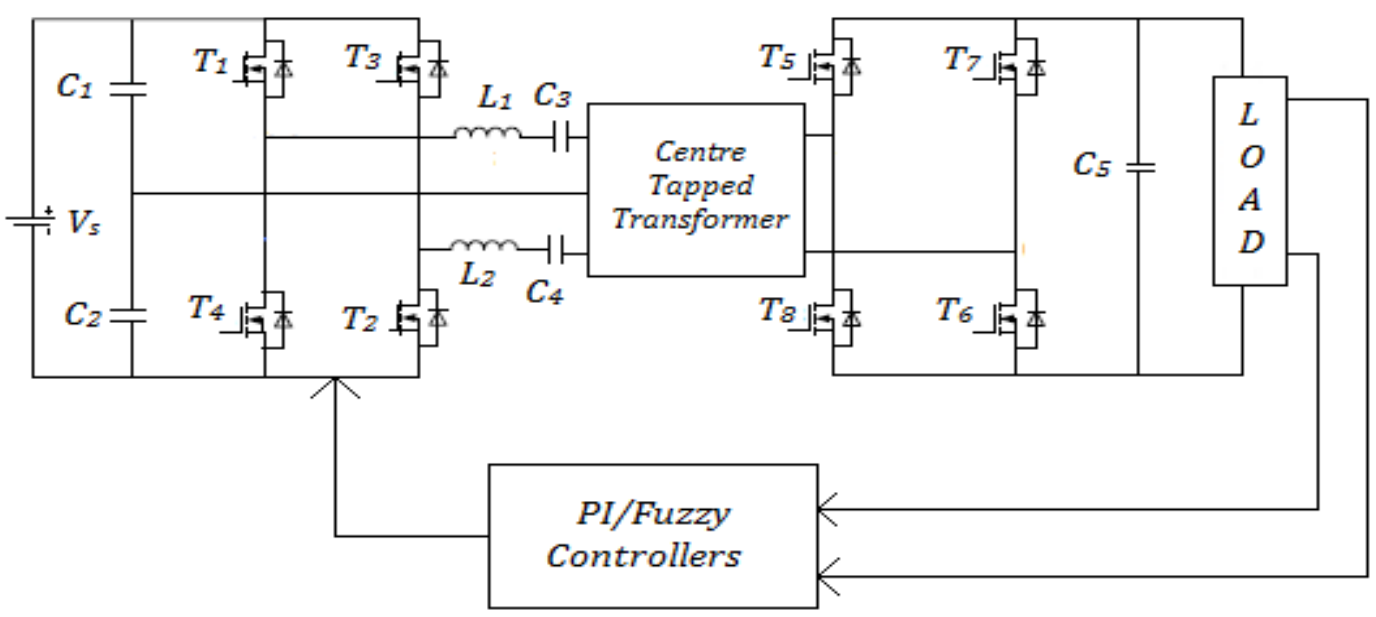

Fig.1 Proposed DTDBSRC Incorporating Proportional Integral and Fuzzy Controller

Fig.1 shows the proposed DTDB series resonant converter circuit with proportional Integral and Fuzzy controller. The proposed circuit mainly consists of three parts, namely (i) Inverter circuit (ii) Resonant tank circuit and (iii) Rectifier circuit. The inverter and rectifier circuits included eight switches (MOSFET: $T_{1}-T_{8}$ ). Every switch connected with an antiparallel diode. Before inverter circuit two capacitors $\left(\mathrm{C}_{1}\right.$ and $\left.\mathrm{C}_{2}\right)$ connected in a single leg.Capacitor $\mathrm{C}_{5}$ is connected in parallel to the load to main the stable voltage crossways the load side. Between the inverter and rectifier circuits, dual resonant tank circuit (series combination of L \& C) and a centre tapped transformer are connected to achieve the soft switching. The proposed converter is controlled by proportional Integral (PI) and Fuzzy controller [8-10].The function of proportional Integral and Fuzzy controller is to uphold the stable output voltage independent of the line and load disturbances [11-13].

\section{SIMULATION RESULTS}

Fig. 2 - Fig. 4 shows the start up as well as transient of DTDB Series Resonant Converter Incorporating Proportional Integral and Fuzzy Controllers under small disturbances in supply 
and load. Fig.2 (a) \& (b) shows the start up voltage and current of DTDBSCR with set point $43 \mathrm{~V}$ and nominal load $320 \Omega$ with PI and Fuzzy controller respectively. Fig.3 (a) \& (b) shows the output voltage and current of DTDBSCR with sudden line disturbances $(220 \mathrm{~V}-225 \mathrm{~V}$ $220 \mathrm{~V}$ ) at 5.2Sec under nominal load of $320 \Omega$ with Proportional Integral and Fuzzy Controller respectively.Fig.4 (a) \& (b) shows the output voltage and current of DTDBSCR with sudden

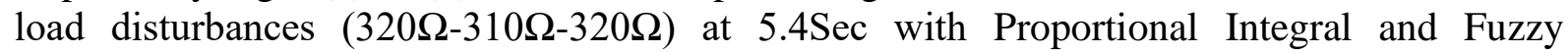
Controller respectively.
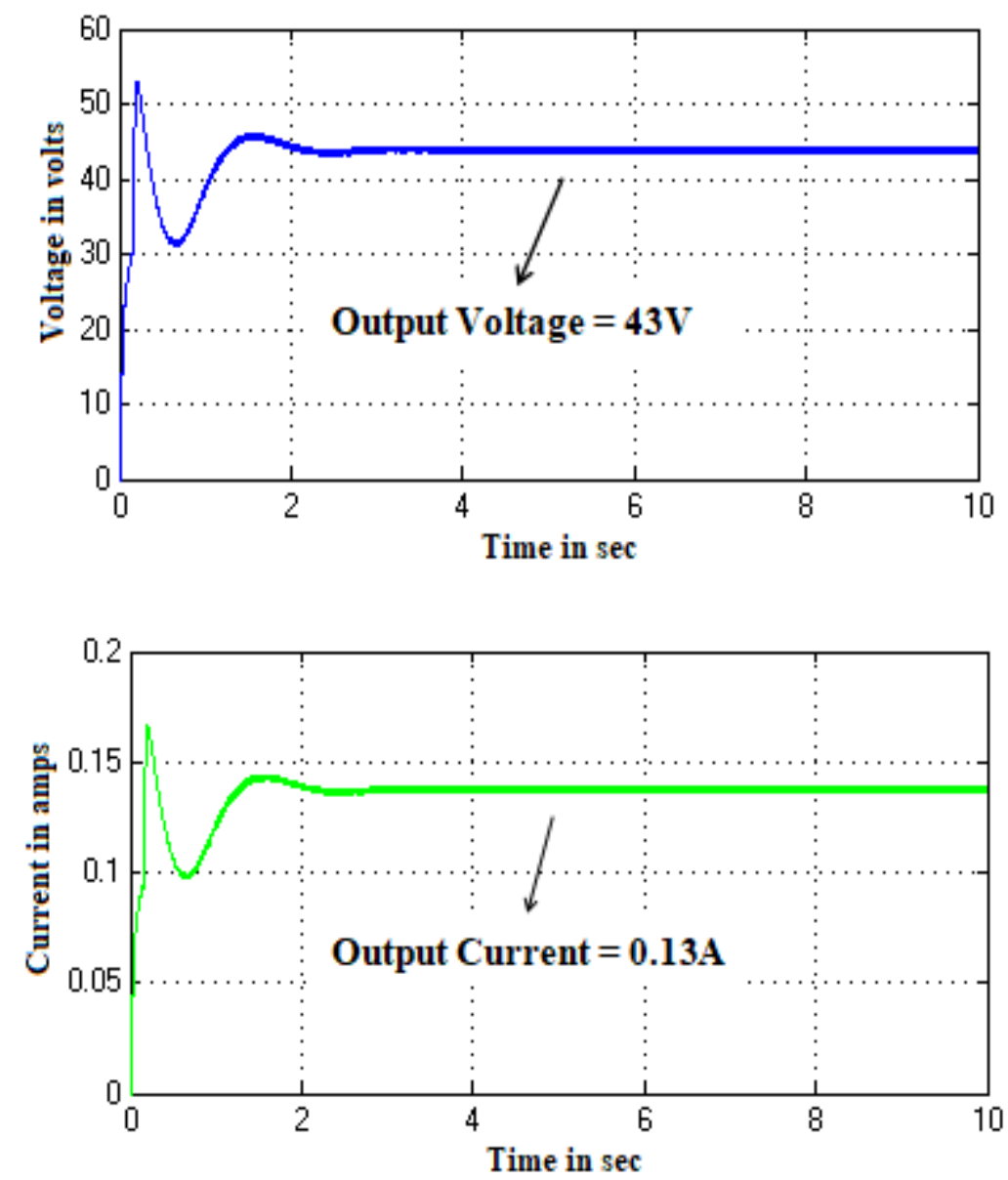

(a) PI Controller

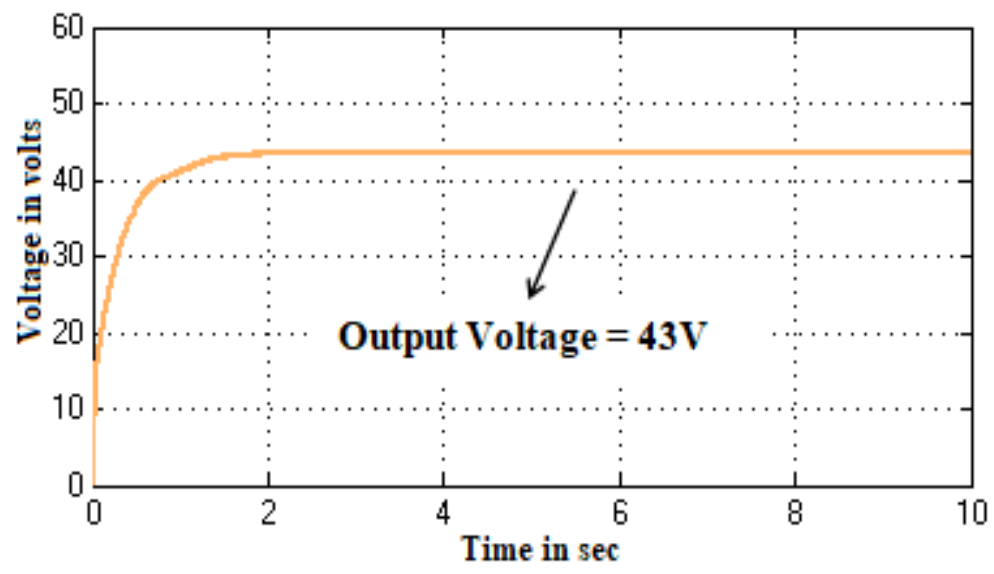


Stability Analysis of Proportional Integral and Fuzzy Controller for Modified Resonant Converter Under Various Disturbances

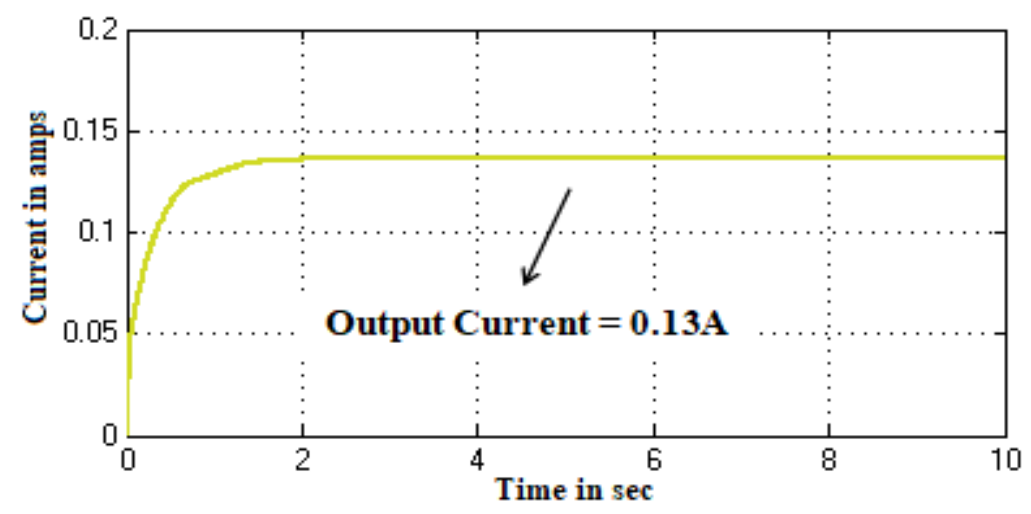

(b)Fuzzy Controller

Fig.2 simulated start-up output voltage and current of DTDBSRC with setpoint $43 \mathrm{~V}$ and Load $320 \Omega$
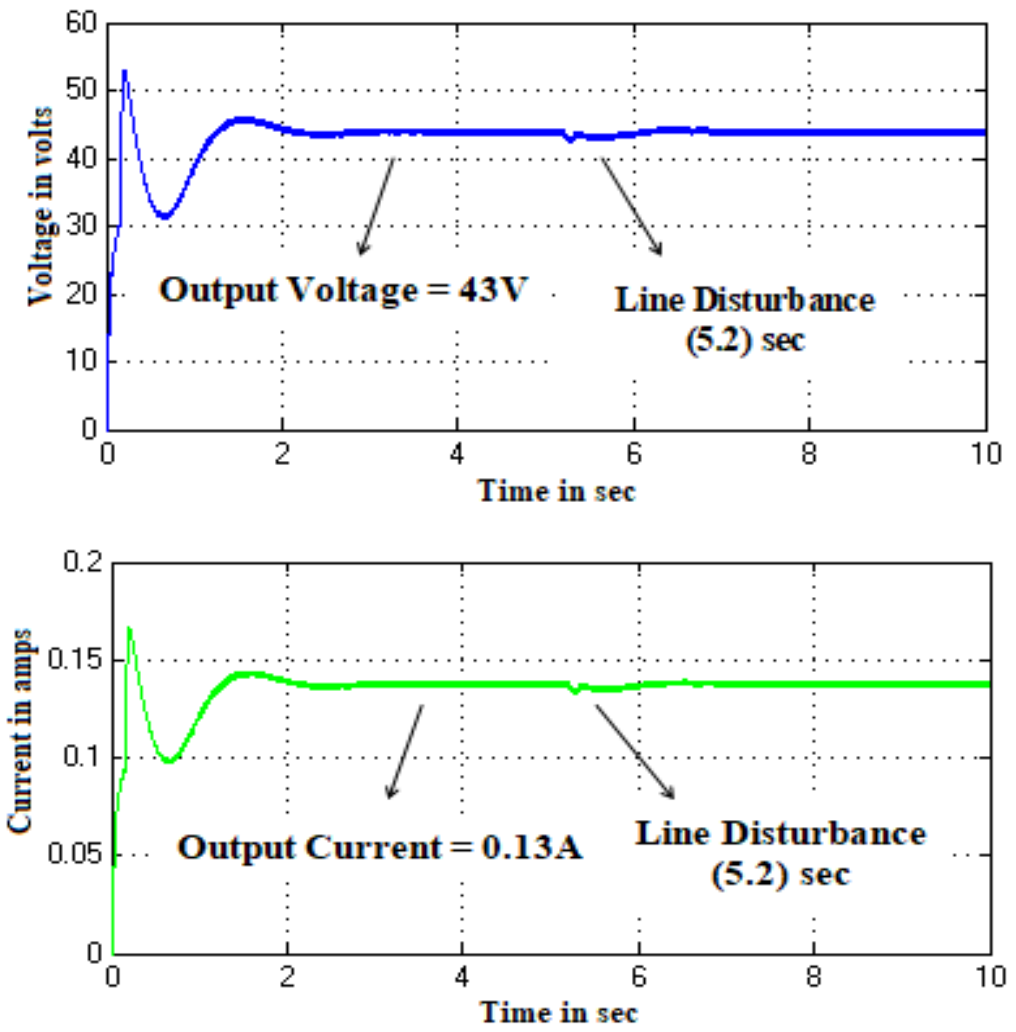

(a)PI Controller

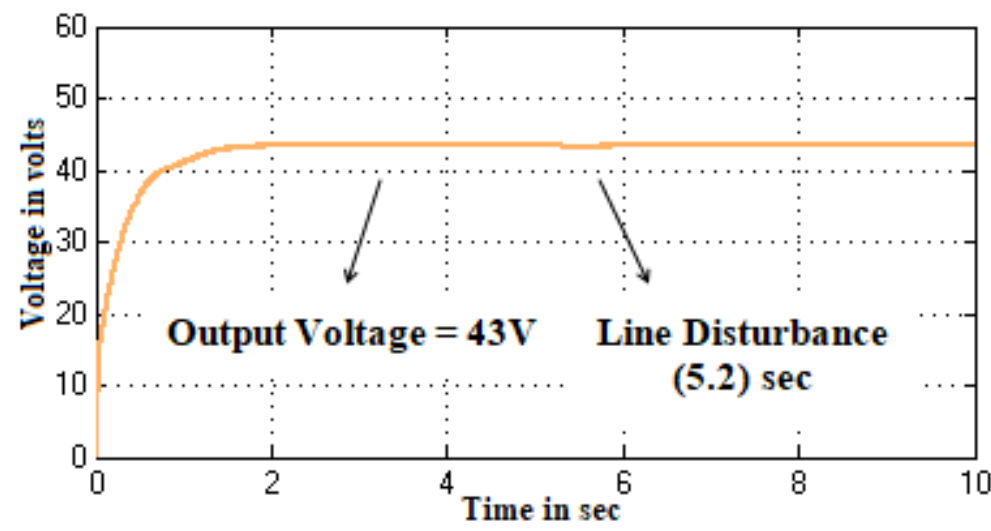




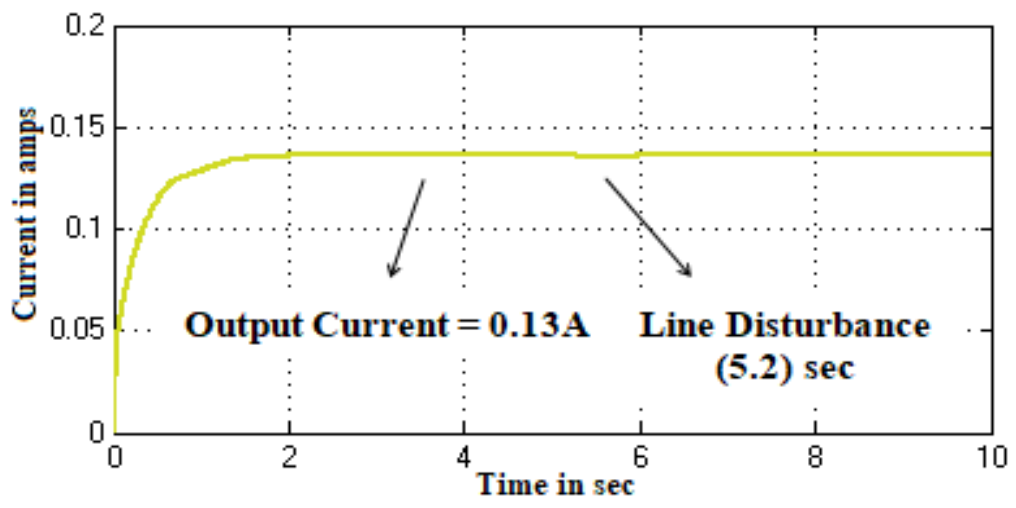

\section{(b)Fuzzy Controller}

Fig.3 Simulated output voltage and current of DTDBSRC with sudden line disturbances (220V-225V-220V) at $5.2 \mathrm{sec}$
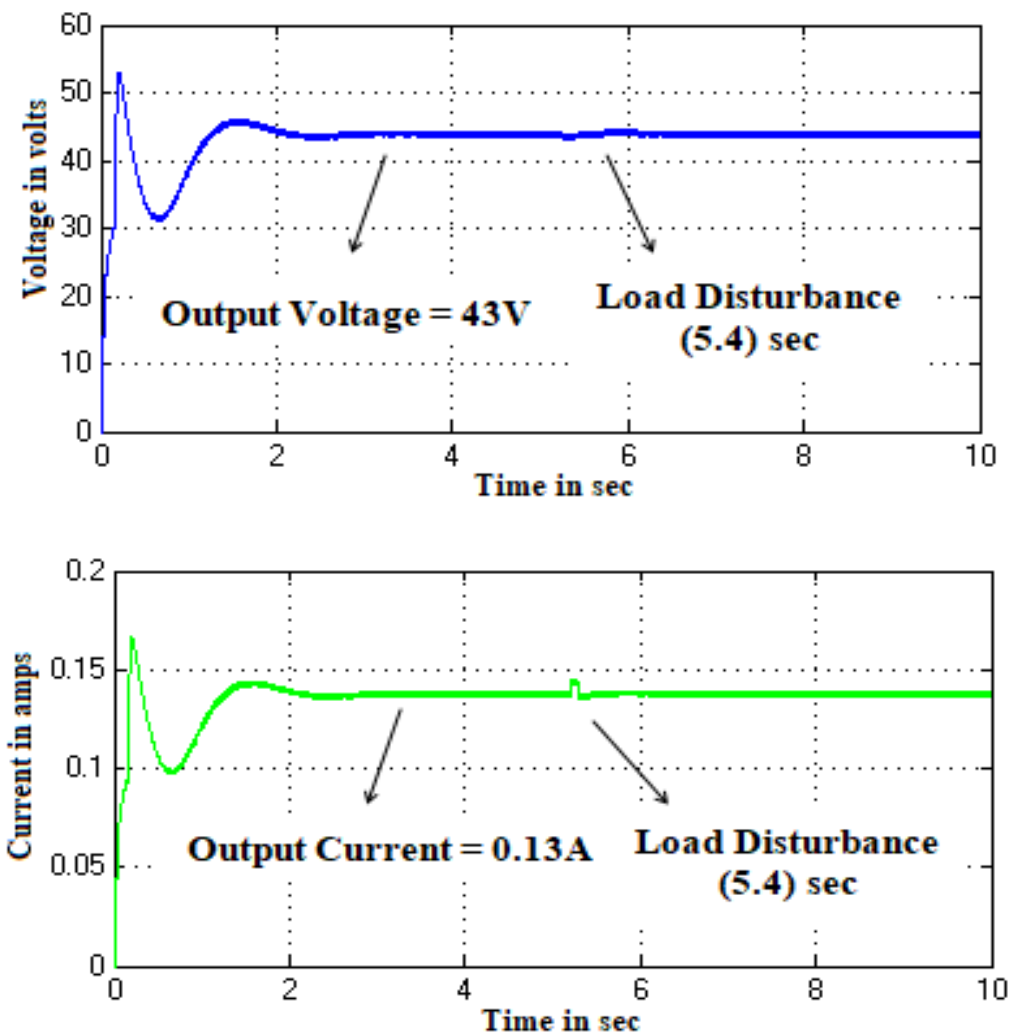

(a) PI Controller

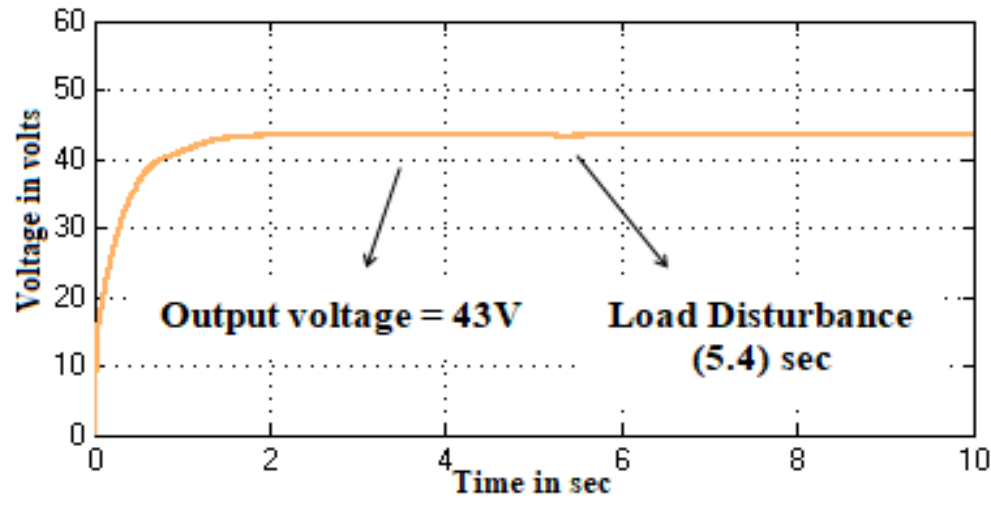




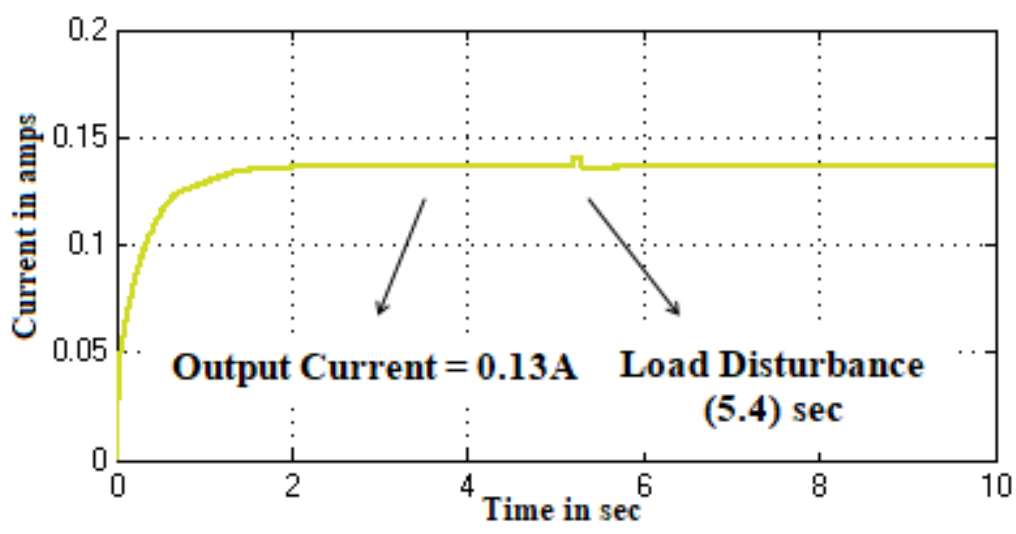

(b)Fuzzy Controller

Fig.4 Simulated output voltage and current of DTDBSRC with sudden load disturbances $(320 \Omega-310 \Omega-320 \Omega)$ at $5.4 \mathrm{sec}$

\section{PERFORMANCE ANALYSIS}

Table .1 shows the stability analysis of Proportional Integral and Fuzzy controller for DTDBSRC with Resistive Load. Fig.5 shows the graphical analysis of controllers for DTDBSRC with Resistive Load using MATLAB. The Time Domain Specifications taken for analysis are Delay Time, Rise Time, Peak Overshoot, Peak Time and Settling Time. The above said specifications are calculated from the results and which is tabulated and charted in Table. 1 and Fig. 5 respectively. First, Delay Time, Rise Time, Peak Overshoot, Peak Time and Settling Time are calculated for startup voltage and current and secondly, the values are

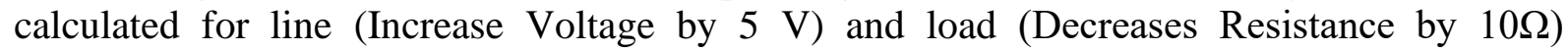
disturbances. From the calculated values, it has been concluded that, Fuzzy Controller act upon better than the proportional Integral (PI) Controller.

Table.1 stability Analysis of controllers for DTDBSRC with Resistive Load

\begin{tabular}{|c|c|c|c|c|c|c|c|c|c|}
\hline \multirow[t]{2}{*}{ Controllers } & \multicolumn{5}{|c|}{ Startup } & \multicolumn{2}{|c|}{$\begin{array}{c}\text { Line } \\
\text { disturbance } \\
\text { (Increase } \\
\text { Voltage by } \\
5 \text { V) }\end{array}$} & \multicolumn{2}{|c|}{$\begin{array}{c}\text { Load } \\
\text { disturbance } \\
\text { (Decreases } \\
\text { Resistance by } \\
10 \Omega \text { ) }\end{array}$} \\
\hline & $\begin{array}{l}\text { Delay } \\
\text { time } \\
\text { (sec) }\end{array}$ & $\begin{array}{l}\text { Rise } \\
\text { time } \\
\text { (sec) }\end{array}$ & $\begin{array}{c}\text { Peak } \\
\text { over shoot }\end{array}$ & $\begin{array}{l}\text { Peak } \\
\text { time } \\
\text { (sec) }\end{array}$ & $\begin{array}{c}\text { Settling } \\
\text { time } \\
\text { (sec) }\end{array}$ & $\begin{array}{c}\text { Peak } \\
\text { over } \\
\text { shoot }\end{array}$ & $\begin{array}{c}\text { Settling } \\
\text { time } \\
\text { (sec) }\end{array}$ & $\begin{array}{l}\text { Peak } \\
\text { over } \\
\text { shoot }\end{array}$ & $\begin{array}{c}\text { Settling } \\
\text { time } \\
\text { (sec) }\end{array}$ \\
\hline PI & 0.1 & 0.3 & 0.23 & 0.2 & 3.2 & 0.20 & 2.8 & 0.20 & 3.2 \\
\hline FUZZY & 0.05 & 0.2 & - & - & 1.9 & - & 2 & - & 2 \\
\hline
\end{tabular}


G.G. Muthukumar, N. Madhanakkumar, G. Irusapparajan and V. Sriramkumar

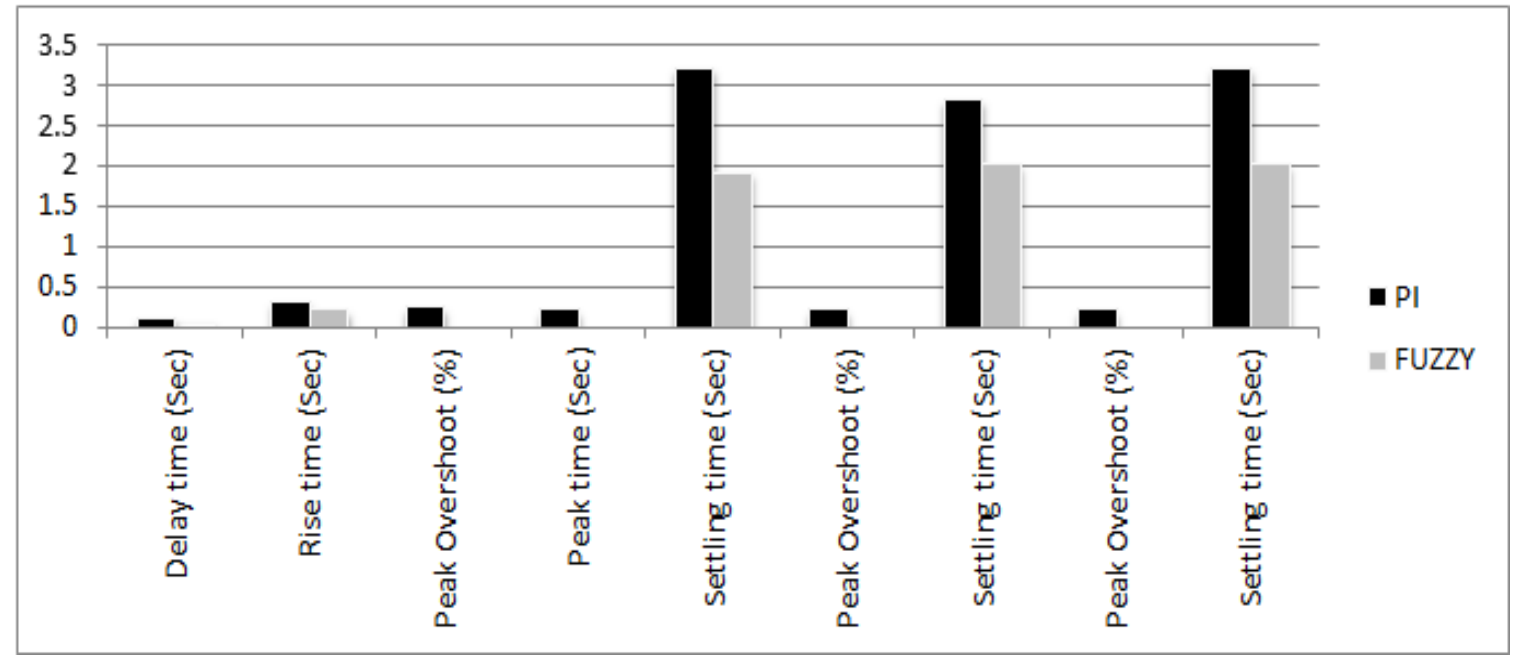

Fig.5 Graphical Analysis of controllers for DTDBSRC with Resistive Load Using MATLAB

\section{CONCLUSION}

The proposed converter incorporated with Proportional Integral and Fuzzy Controller was designed using MATLAB Simulink. From the above table and graphical chart, it has been observed that during Startup, PI controller takes 0.1 Sec and Fuzzy controller takes only 0.05 Sec to reach delay time. To achieve Rise time, PI controller takes $0.3 \mathrm{Sec}$ and Fuzzy controller takes only 0.2 Sec. Fuzzy controller produced No Peak overshoot, but PI Controller have 23 percentage of peak overshoot. Peak time achieved at $0.2 \mathrm{Sec}$ by PI Controller. But Fuzzy Controller has No peak time. To achieve settling time, PI Controller takes 3.2 Sec and Fuzzy Controller takes only 1.9 Sec. During Line disturbance, PI Controller has 20 percentage of peak overshoot and Fuzzy has No peak overshoot. PI Controller takes $2.8 \mathrm{Sec}$ to reach settling time and Fuzzy takes only 2 Sec. During Load disturbance, PI Controller has 20 percentage of peak overshoot and Fuzzy has Nopeak overshoot. PI Controller takes 3.2 Sec to reach settling time and Fuzzy takes only 2 Sec. From above stated analysis, it has been concluded that Fuzzy controller has better performance than Proportional Integral Controller. In future, the proposed converter may be designed with Neural Controller to achieve further better performances.

\section{REFERENCES}

[1] Junjuan Wu, Yuci Li, Xiaofeng Sun, Feilong Liu (2017) "New Dual-Bridge Series resonant DC-DC converter with dual-tank" IEEE Transactions on Power Electronics, DOI 10.1109/TPEL.2017.2723640

[2] Y.Chéron, (1992) "Soft Commutation", Springer Netherlands.

[3] F. Krismer, J. W. Kolar, (2012) "Efficiency-optimized high-current dual active bridge converter for automotive applications," IEEE Trans. Ind. Electron., vol. 59, no.7, pp.2745-2760, Jul.

[4] B. Zhao, Q. Song, W. Liu, Y. Sun, (2014) "Overview of Dual-Active-Bridge Isolated Bidirectional DC-DC Converter for High-Frequency-Link Power-Conversion System," IEEE Trans. Power Electron., vol. 29, no.8, pp. 4091-4106, Oct.

[5] N.Madhanakkumar, T.S.Sivakumaran, G.Irusapparajan, D.Sujitha, (2014) "Closed Loop Control of LLC Resonant Converter Incorporating ZVS Boost Converter" International Journal of Engineering and Technology, Vol 6 No 2 Apr-May 
[6] N.Madhanakkumar \& T.S.Sivakumaran, April-June (2016), 'Comparative study of closed loop control for resonant converter incorporating boost converter utilizing compression network', International Journal of Advanced Engineering Technology, vol.7, issue.2, pp. 85-92.

[7] N.Madhanakkumar \& T.S.Sivakumaran, 17 May (2016), 'Performance Analysis of PI and Fuzzy control for Modified LLC Resonant converter incorporating boost converter' Scientific Research Publishing, Circuits and Systems 7, pp. 835-848.

[8] Lee, CC (1990), 'Fuzzy logic in control systems: fuzzy logic controller-part 1 and part 2', IEEE Transaction System, Man and Cybernatics, vol. 26, no. 16, pp. 404-436.

[9] So, WC, Tse, CK \& Lee, YS (1996), 'Development of a fuzzy logic controller for DC/DC converters: design, computer simulation and experimental evaluation', IEEE Transaction Power Electronics, vol. 11, no. 1, pp. 24-32.

[10] Mattavelli, P, Rossetto, L, Spiazzi, G \& Tenti, P (1997), 'General - purpose fuzzy controller for DC - DC converters', IEEE Transaction Power Electronics, vol. 12, no. 1, pp. 79-85.

[11] D. Periyaazhagar, G.Irusapparajan, (2016) 'Asymmetrical cascaded multi level inverter using control freedom pulse width modulation techniques', International Journal of Power Electronics and Drive System.Vol.7, Issue 3, pp 848-856.

[12] D. Periyaazhagar, G.Irusapparajan, (2016) 'Comparative study on three phase cascaded inverter for various bipolar PWM techniques', International Journal of Modelling, Identification and Control. Vol. 25, Issue 4, pp 261-272.

[13] G. Irusapparajan, D. Periyaazhagar, N. Prabaharan and A. Rini ann Jerin, (2019) 'Experimental verification of trinary DC source cascaded H-bridge multilevel inverter using unipolar pulse width modulation', Automatika, Journal for Control, Measurement, Electronics, Computing and Communications, Vol. 6, Issue 1, pp.19-27.

[14] K. Vishnu Murthy, L. Ashok Kumar, N. Sampathraja and Y. Dhayaneswaran, (2017) Solar Powered Speed Control of Brushless DC Motor Drive using PID Fuzzy Controller, International Journal of Mechanical Engineering and Technology, 8(8), pp. 1135-1147

[15] Peram Subba Rao, Dr.K.Venkata Rao, Dr.P.Suresh Varma, (2013) A Novel Software Interval Type - 2 Fuzzy Effort Estimation Model Using S-Fuzzy Controller with Meanand Standard Deviation, International Journal of Computer Engineering and Technology, 4(3), pp. $477-490$ 